\title{
An asset-based approach in career facilitation: Lessons for higher education training
}

\author{
S. Coetzee \\ Department of Educational Psychology \\ University of Pretoria \\ South Africa \\ L. Ebersöhn \\ Department of Educational Psychology \\ University of Pretoria \\ South Africa \\ e-mail: liesel.ebersohn@up.ac.za

\section{R. Ferreira} \\ Department of Educational Psychology \\ University of Pretoria \\ South Africa
}

\begin{abstract}
This exploratory and descriptive study investigated the use of the asset-based approach in career facilitation in South Africa. Five adolescents (3 females and 2 males) aged 16 to 18 years participated. An intervention study following a qualitative approach was conducted. We developed and implemented an asset-based career facilitation intervention that included psychometric and post-modern career activities. We used multiple data collection strategies (observation, unstructured interviews, intervention activities, visual data and participant reflections), which we documented in various ways (field notes, researcher diaries, photocopies of intervention artefacts and participant reflective diaries). Our thematic analysis of the data revealed three main themes. Firstly, in terms of the client-partner relationship, the study indicated the significance of personality traits, age, family dynamics, career interest profiles and previous career assessment experiences when using asset-based strategies. Secondly, the challenging role of the asset-based career facilitator was emphasised. Thirdly, results suggested that traditional career guidance paradigms meant that client-partners expected the career facilitator to function as expert, and accordingly resisted the shared responsibility of partnership. Subsequently, we identified indicators and contra-indicators for using assetbased career facilitation.
\end{abstract}

\section{BACKGROUND AND RATIONALE}

Current developments in career counselling theory and practice (Maree and Ebersöhn 2007) suggest that South African higher education institutions are experiencing changes in knowledge construction and professional training. Theoretically, career 
facilitation has been exposed to renewal with the contesting of positivist practices and calls for innovative, qualitative procedures emerging in various studies (Ebersöhn 2007b; Maree 2007; McMahon and Patton 2002; Savickas 2005; Watson 2004). Contextually, South Africa's unique socioeconomic and educational variables require similar pioneering theoretical and practical career facilitation initiatives in research and training (Cosser 2002; Maree and Beck 2004).

Even in the post-apartheid education realm, formal and informal career guidance remains the privilege of affluent, white, urban citizens (Akhurst and Mkhize 2006). Also, career guidance instruments are slanted towards the latter group without necessarily addressing the career pathing needs of the marginalised majority (Nicholas, Naidoo and Pretorius 2006). By implication, most South Africans do not have access to career facilitation services, and, for those who do have access, the services are conceptualised for a different group (Jassat, Akhurst and Adendorff 2006). In view of these opposing trends, the training of educational psychologists in career facilitation at higher education institutions calls for reconceptualisation.

To our minds, one way in which this career guidance conundrum can be dealt with is by incorporating asset-based approach principles into career facilitation research and consequently training and professional practice. An asset-based approach takes into cognisance what one has available internally and externally to facilitate success - also in terms of career development (Ebersöhn and Eloff 2006). Thinking and working from an asset-based approach in career facilitation implies that (irrespective of demographic variables) each client's existing resources are lobbied to meet career pathing requirements. Likewise, asset-based strategies offer a fresh point of departure (aligned with post-modern thinking) to assess career choice and intervene for career facilitation purposes. Based on these theoretical contentions, we endeavoured with this exploratory study to investigate how an asset-based approach could be used in career facilitation.

For these reasons our exploratory research question was: How can insights into innovative career facilitation be informed when implementing an asset-based intervention? Similarly the following secondary research questions guided our investigation and subsequent descriptions: What is the nature of an asset-based career facilitation intervention? Which outcomes arise for clients when implementing an asset-based career facilitation intervention?

\section{LITERATURE OVERVIEW}

\section{Asset-based approach: recognising resources in conjunction with barriers}

Coetzee $(2005,13)$ sees an asset-based approach as illustrating 'the importance of a systems approach and [as] fundamentally a support-based and relationship driven theory which aims at recognising assets, mobilising these assets and creating sustainable skills'. Table 1 reflects our conceptualisation of the fundamental underpinnings of an asset-based approach. 
Table 1: Proposed components of an asset-based approach

\begin{tabular}{|c|c|}
\hline $\begin{array}{l}\text { Fundamental } \\
\text { underpinning }\end{array}$ & Conceptualisation \\
\hline Nature of people & $\begin{array}{l}\text { - People are able to adapt and to cope and make their own decisions, thus } \\
\text { - Personal agency. } \\
\text { - People are characterised by assets and barriers. } \\
\text { - People kossess assets that they may not recognise or mobilise. } \\
\text { - People are part of a broader community. } \\
\text { - The broader community consists of individuals, local associations and local } \\
\text { institutions that can contribute to an intervention process. }\end{array}$ \\
\hline $\begin{array}{l}\text { Theory of } \\
\text { intervention }\end{array}$ & $\begin{array}{l}\text { - Intervention is a process of support. } \\
\text { - Assets are identified, accessed and mobilised during intervention and kept as } \\
\text { resources for future sustainable utilisation. } \\
\text { - An intervention's aim is to facilitate, develop and mobilise sustainable skills. } \\
\text { - Intervention denotes a safe place where skills and vulnerabilities can be } \\
\text { shared by facilitator and client-partner. } \\
\text { - Intervention is relationship driven and functional. } \\
\text { - Intervention constitutes a cycle of enablement rather than dependence. } \\
\text { - Intervention is essentially proactive. } \\
\text { - Intervention is network based, therefore the asset-based practitioner and } \\
\text { client-partner acknowledge other individuals, local associations and local } \\
\text { institutions as possible assets that may be mobilised. }\end{array}$ \\
\hline $\begin{array}{l}\text { Intervention } \\
\text { methods }\end{array}$ & $\begin{array}{l}\text { - Interviews. } \\
\text { - Observation. } \\
\text { - Post-modern exploration strategies. } \\
\text { - Asset mapping: the process of making a graphic representation of identified } \\
\text { assets visual is intended to initiate the process of asset mobilisation. } \\
\text { - Quadrant mapping: the process of making a graphic quadrant representation } \\
\text { of individual and environmental resources and barriers. } \\
\text { - Asset mobilisation. } \\
\text { - Networking and collaboration. }\end{array}$ \\
\hline Constructs used & $\begin{array}{l}\text { - Assets / resources / signature strengths. } \\
\text { - Identify / map / mobilise / network. } \\
\text { - Partnerships / collaboration. } \\
\text { - The individual. } \\
\text { - The school. } \\
\text { - The classroom. } \\
\text { - The family. } \\
\text { - The peer group. } \\
\text { - Citizens' associations. } \\
\text { - Local institutions. } \\
\text { - The whole social system. }\end{array}$ \\
\hline
\end{tabular}

(Compiled from Coetzee 2005; Ebersöhn and Eloff 2003 and 2006)

Ebersöhn and Eloff (2006) explain asset-based processes by stating that, when a career facilitator applies an asset-based approach, s/he becomes aware of assets, resources and capacities in a client's given environment. In this process, assets are co-identified through routes of quadrant mapping (where assets as well as 
risk factors are mapped), collaboration and relationship building. Asset accessing requires co-evaluation of the value of an existing asset in relation to a career choice. The course of action to access assets is dependent on the facilitator and client's continued prioritisation. In the same way, career facilitation role players continually and collaboratively mobilise assets. In an asset-based approach, sustainable asset mobilisation and development are generally inherent in committed clients - as signified by their ownership of career decisions. By the same token, deficiencies are also taken into account in the quest for accountable responses to a specific challenge. As Ebersöhn and Eloff $(2006,8)$ explain:

Even though lack/scarcity/flaws/shortcomings do not constitute the central focus of asset-focused ... facilitation, they constitute elements of the backdrop of the intervention process. In some instances, they remain the implicit goal of the intervention. For example, assets and strengths are identified, accessed, mobilised and sustained in order to address lack/scarcity/flaws/shortcomings.

To our minds, recognising resources as well as needs strengthens an asset-based approach. We see value in the integration of an asset-based and needs-based approach. Although a needs-based approach trains us to establish deficits and does not automatically acknowledge the abilities or resources that client-partners acquire throughout their lifespan, we accept the reality of the existence of deficits and strengths. This asset-based conceptualisation recognises that the glass is both halffull and half-empty (Ebersöhn and Eloff 2006). In this regard, Wright and Lopez (2002) emphasise the importance of highlighting positives as well as negatives in the person and environment as such an approach provides the framework for individualised intervention whereby human potential is discovered.

Forgetting that individuals may not feel comfortable in certain occupational settings, due to a lack of ability, is as dangerous as not remembering that they may have other abilities that will enable them to excel in other occupational settings. It is a matter of reorganising the way in which helping professionals apply intervention skills. In this conceptualisation, quadrant mapping (Ebersöhn and Eloff 2006) is an example of a diversified emphasis.

\section{Asset-based approach: a post-modern career facilitation alternative}

In recent times, it would seem that the post-modern perspective of Savickas 'adds a personal flavour to the process of career counselling' (Maree 2002, 25). Maree $(2002,25-26)$ states that 'the [post-modern] approach provides potential protection against inaccurate diagnosis and incorrect application of technology, including tests and inventories'. A post-modern perspective is considered a viable alternative to traditional career theories (Richardson 1993; Savickas 1993). We illustrate similarities between an asset-based approach and post-modern perspectives in career development in Table 2. 
An asset-based approach in career facilitation: Lessons for higher education training

Table 2: $\quad$ Similarities between the post-modern perspective and an asset-based approach

\begin{tabular}{|c|c|}
\hline An asset-based career facilitation process & Post-modern perspective \\
\hline - Create a cycle of enablement. & $\begin{array}{l}\text { - Encouragement and expression of self- } \\
\text { development (Maccoby 1981); enable rather } \\
\text { than fit (Lather 1991). }\end{array}$ \\
\hline $\begin{array}{l}\text { - Subjective understanding of the client- } \\
\text { partner and shared knowledge. }\end{array}$ & - Move towards perspectivity (Maree 2002). \\
\hline - Person-centred perspective. & - Person-centred perspective (Maree 2002) \\
\hline $\begin{array}{l}\text { - Networking, collaborative and relationship- } \\
\text { based career facilitation. }\end{array}$ & $\begin{array}{l}\text { - Teamwork through co-operation and emphasis } \\
\text { on relationship (Savickas 1996; 1993). }\end{array}$ \\
\hline - Client-partner is the expert. & $\begin{array}{l}\text { - No more career experts - clients are treated as } \\
\text { co-counsellors who interpret their own needs } \\
\text { and shape their own lives from a range of } \\
\text { possibilities (Lather 1991). }\end{array}$ \\
\hline $\begin{array}{l}\text { - Collect information regarding assets from } \\
\text { bio-ecological system. }\end{array}$ & $\begin{array}{l}\text { - Active participation in the community (Savickas } \\
\text { 1996; 1993). }\end{array}$ \\
\hline - Client-partners have essential viewpoints. & $\begin{array}{l}\text { - Career counselling has shifted from finding an } \\
\text { optimal fit to meaning making (Maree 2002). }\end{array}$ \\
\hline - Sustainability of skills in the client-partner. & $\begin{array}{l}\text { Establish which skills are needed to write the } \\
\text { next chapter of their life stories and acquiring } \\
\text { those skills (Savickas 1993). }\end{array}$ \\
\hline
\end{tabular}

(An integration of Ebersöhn and Eloff (2003) and Maree (2002))

Table 2 shows the common ground found in post-modern perspectives and an assetbased approach. In this regard, Patton $(2005,26)$ says that 'a post-modern approach to career education adopts very different theoretical and pedagogical underpinnings than approaches based on trait-factor notions of career choice and industrial era notions of education and work'. The ultimate difference is that post-modern career approaches focus on work experience and context and thus move away from 'finding a good fit between worker and workplace' towards 'validating individuals' unique career experiences' (Thrift and Amundson 2005, 10).

Whereas post-modern career counsellors draw strongly on narrative therapy techniques (Maree 2002), asset-based career facilitation as a post-modern methodology relies on asset mapping or quadrant mapping (Ebersöhn and Eloff $2006)$ to focus on capacities. Maree $(2002,27)$ explains that 'career counselling has become more reliant on autobiographies (life stories) than on results of "objective testing"; our lives are interpreted as texts and careers as stories'. We posit that assetbased strategies can be used during story telling and 'restorying' (Krieshok, Hastings, Ebberwein, Wettersten and Owen 1999, 212) to foreground existing resources and depict previous patterns of decision making as a means of using assets to address barriers.

An asset-based process provides a post-modern way in which an asset-based facilitator recognises and focuses on the giftedness of the individual (Ebersöhn and 
Eloff 2006). Likewise, through mapping, the facilitator can help the individual reach (career) goals. As the two approaches are similar, we believe that incorporating mapping into narrative techniques can result in contextually based self-knowledge that can support decision making in client-partners. Asset mapping (where sources of information are stipulated) can thus be integrated as a roadmap for the grand narrative of the client-partner.

\section{Career facilitation}

Prinsloo (1999) suggests the term career facilitation as a more comprehensive alternative to career counselling. She (Prinsloo 1999) holds that career facilitation is more than education as the client is viewed in his/her totality and the facilitator is conscious of the client's other life roles. The facilitation process helps the career facilitator move away from the deficit model. Deficit model thinking requires the career counsellor to fix the client's problem of not knowing what career to pursue (Moore and Rapmund 2002). Consequently, the fundamentals of career facilitation correspond with the essential characteristics of an asset-based approach (Coetzee 2005).

Career facilitation is a compound term for other terms describing the career helping process but with the distinct difference that it integrates assets from the client-partner as well as the client-partner's environment (Coetzee 2005). This process includes such principles as client-partner ownership, shared responsibility, enablement, recognition of sustainable skills and collaborative views.

An asset-based approach and the process of career facilitation share a common goal, which is to enable people to help themselves and to 'manage their own careers' (Savickas 1997, 256). This objective of self-enablement and sustainability of skills can increase client-partners' existing abilities and prepare them for the next career (Patton 2001). In contrast to what was previously perceived as career helping, the notion of enablement is not necessarily expressed in terms of concepts such as career counselling, career guidance or career education (Coetzee 2005).

\section{Aligning asset-based principles with career facilitation}

Helping nowadays means moving away from a focus on the expert knowledge and skills of the career counsellor. Traditionally, career counsellors are expected to know all there is to know about any career thus entitling them 'to decide for' a client. An asset-based approach suggests that helping can be a pluralistic effort where career counselling becomes a process of facilitation. Career facilitators can use their counselling expertise to facilitate career development. The contexts surrounding the career facilitator and the client-partner are wide and rich with information and resources. Studies on psychosocial resilience illustrate how the different levels of the bio-ecological model (referred to as the eco-systemic perspective in Swart and Pettipher 2005, as well as Donald, Lazarus and Lolwana 2002) can contribute to mental health. Such studies often list general protective factors against developmental hazards (Ebersöhn 2007a; Masten and Reed 2002). 
We view protective factors as resources which include personal strengths (an adaptable personality, a positive self-perception, a sense of faith and meaning in life, a positive outlook on life, good self-regulation of emotional awareness, talents valued by self and society, a sense of humour, general appeal to others); resources within the family (close relationships with care-giving adults, authoritative parenting, positive family climate, organised home environment, parents involved in children's education, socioeconomic advantages); capacity within relationships (close relationships with competent, pro-social and supportive adults); connections with pro-social and rule-abiding peers (good schools, ties with pro-social organisations such as clubs); and community assets (neighbourhoods with high collective efficacy, high levels of public safety, good emergency social services, good public health and health care availability).

The stance of helping professionals on their approach and intervention emphasis may shift in quadrant thinking (Coetzee 2005; Ebersöhn and Eloff 2006) thereby expanding some quadrants and shrinking others. In terms of career facilitation, the career facilitator could focus deficiencies such as the qualities the client-partner needs (and does not possess), highlight the lack of resources and give expert advice on eliminating career options based on these deficiencies, possibly leaving the client powerless. Conversely, the facilitator could focus on the client's signature strengths, assets and capacities. S/he could facilitate relationships and networking to explore career options that emphasise the gifts and talents of the client-partner leaving the client-partner with a possible sense of ownership and sustainable skills. Once a client-partner mobilises existing strengths, talents, capabilities and gifts effectively, more challenging areas can be addressed with greater enthusiasm.

\section{METHOD}

The investigation was based on an interpretivistic paradigm (Denzin and Lincoln 1998) involving understanding and interpreting meanings as they are revealed during interactions. The intervention design (Rothman and Thomas 1994) foregrounded the case of career guidance among adolescents. The particular participants were purposefully selected (McMillan and Schumacher 2001), and their details are given in Table 3. Selection criteria called for adolescents who had been referred for career guidance by educational psychologists to the private educational psychology practice of one member of the research team. Participants D and E were selected for theme saturation purposes (Creswell 2005; Durrheim 2002).

Table 3: Participant details

\begin{tabular}{|l|c|c|c|c|c|c|}
\hline Participant & Age & Grade & Gender & Aptitude & Sessions & Hours \\
\hline A: The Thinker & 17 & 12 & Male & Superior & 4 & 6 \\
\hline B: The Golfer & 17 & 11 & Male & Superior & 5 & 7,5 \\
\hline C: The Undecided & 16 & 10 & Female & Above average & 8 & 12 \\
\hline
\end{tabular}




\begin{tabular}{|l|c|c|c|c|c|c|}
\hline D: The Architect & 17 & 11 & Female & High average & 6 & 9 \\
\hline E: The Decided & 18 & 12 & Female & Above Average & 6 & 2 \\
\hline
\end{tabular}

An asset-based career facilitation intervention was developed and implemented individually with each participant in the study (Coetzee 2005). The intervention incorporated theoretical assumptions on an asset-based approach, career facilitation and career development tasks (Langley 1999). The focal point of each session included the following goals: (i) focus on the assets and capacities of the participants; (ii) identification of values, interests and other relevant factors through shared knowledge and connecting relationships; (iii) asset-based career facilitation as a service aimed at achieving an inspiring cycle of enablement; and (iv) respecting participants as client-partners and experts. Various instruments were accordingly used during the intervention including personal asset maps, collages, reports from relatives and friends, previous career counselling information and reports, and descriptions of strengths and assets according to the scored results of the Myers-Briggs Type Indicator ${ }^{\circledR}$ (Van Rooyen, De Beer and Proctor 2001). As each participant's life-world constituted a unique combination of assets and barriers (Ebersöhn and Eloff 2006), the intervention sessions were adjusted according to the specific needs and assets of the individual participant. Table 4 provides an overview of the session goals and each participant's session participation.

Table 4: Intervention schedule with various participants

\begin{tabular}{|c|c|c|}
\hline Session & Goal & Participant \\
\hline 1 & $\begin{array}{l}\text { Explain the research project. } \\
\text { Introduce the career facilitation process. } \\
\text { Establish rapport. } \\
\text { Ascertain expectations of participant. }\end{array}$ & $A, B, C, D, E$ \\
\hline 2 & $\begin{array}{l}\text { Administer MBTI (not E). } \\
\text { Administer post-modern media (not D, E). } \\
\text { Acquire self-knowledge. } \\
\text { Administer job analysis questionnaire (only D). } \\
\text { Discuss information obtained through previous career } \\
\text { assessment (only E). }\end{array}$ & $A, B, C, D, E$ \\
\hline 3 & $\begin{array}{l}\text { Discuss post-modern media (not D). } \\
\text { Compile a personal asset map (not D). } \\
\text { Visit architect (only D). }\end{array}$ & $A, B, C, D$ \\
\hline 4 & $\begin{array}{l}\text { Recap previous session / discuss post-modern media. } \\
\text { Explore different career interests. } \\
\text { Discuss personal asset map. }\end{array}$ & $\mathrm{C}$ \\
\hline 5 & Discuss homework activity & $\mathrm{C}$ \\
\hline 6 & Discuss homework activity & $\mathrm{C}$ \\
\hline 7 & $\begin{array}{l}\text { Discuss career goal (all participants). } \\
\text { Discuss post-modern media (only B). } \\
\text { Discuss homework assignment (only B). }\end{array}$ & $\begin{array}{l}\text { B, C, D, E } \\
\text { (D: the session goals for } \\
\text { Session } 7 \text { occurred over two } \\
\text { separate sessions; }\end{array}$ \\
\hline
\end{tabular}




\begin{tabular}{|l|l|l|}
\hline Session & Goal & Participant \\
\hline & $\begin{array}{l}\text { Visit architect (only E). } \\
\text { Reflect on the career facilitation process (all participants). }\end{array}$ & $\begin{array}{l}\text { E: the session goals for Session } \\
7 \text { occurred over three separate } \\
\text { sessions). }\end{array}$ \\
\hline
\end{tabular}

Qualitative data sources to investigate our research questions were (i) observation (Angrosino and Mayz de Pérez 2000) by the investigator documented in field notes and a research diary (McMillan and Schumacher 2001); (ii) participant reflections documented in participant diaries (McMillan and Schumacher 2001); (iii) informal conversational information (Creswell 2005) during the intervention between the participant and the researcher/facilitator - recorded and transcribed; and (iv) visual data of the intervention artefacts of the participants documented as photocopies (Ebersöhn and Eloff 2007). Figures 1-3 include a few examples of the visual data of intervention artifacts we collected.

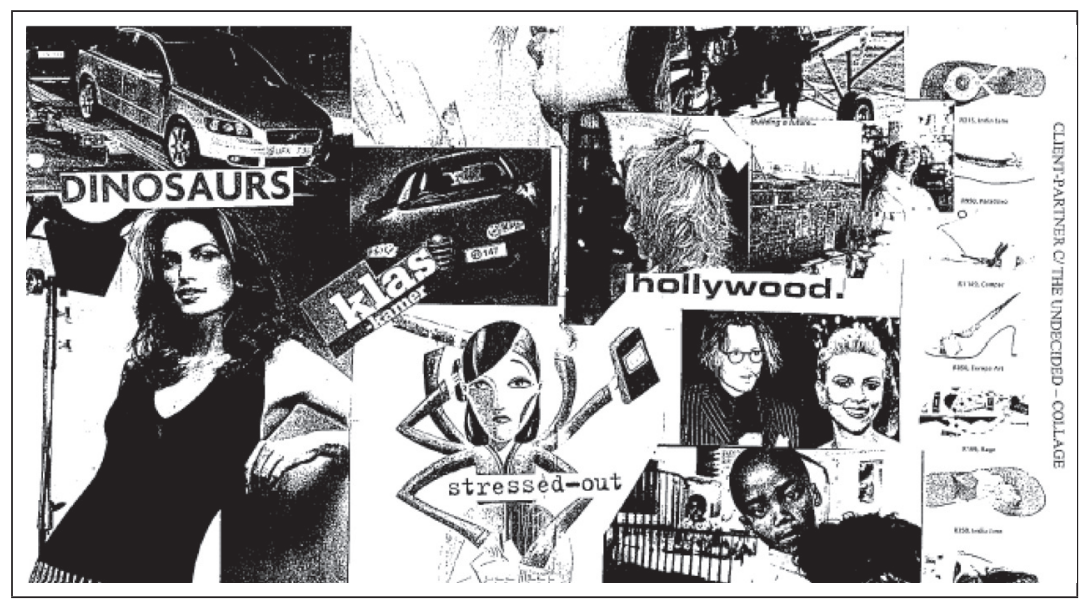

Figure 1: Example of a collage made by a participant

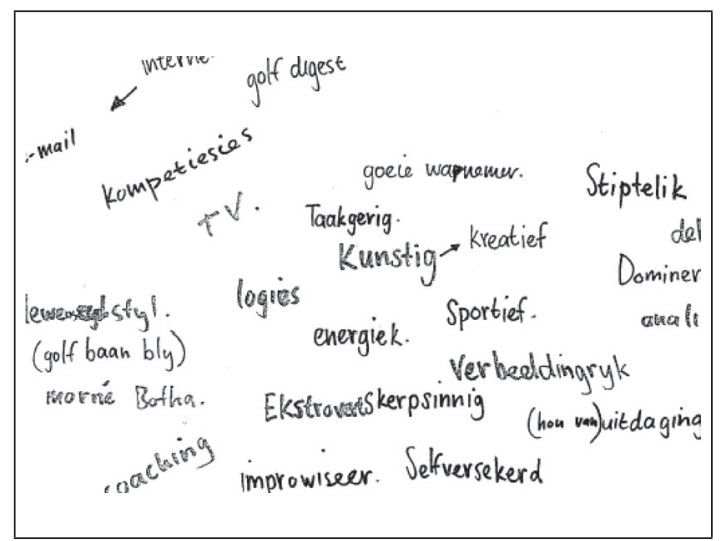

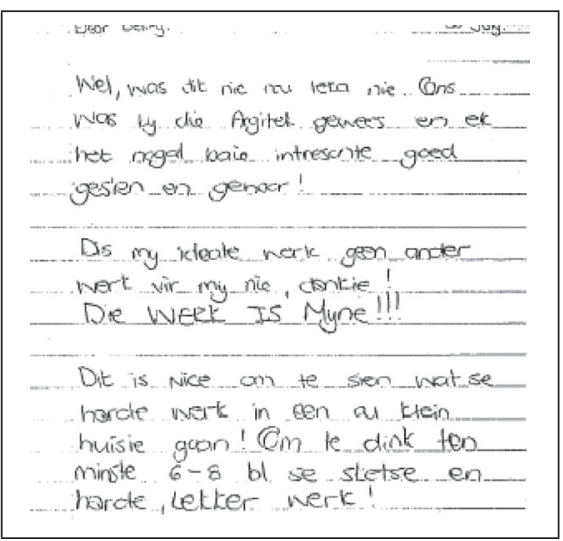

Figure 2: (left) Example of an asset-map made by a participant

Figure 3: (right) Example of a diary entry made by a participant 
For the purpose of data analysis, the documented data were thematically analysed by organising and identifying data as categories, themes and patterns. Finally, the data were evaluated and categorised (Marshall and Rossman 1989). A literature control was subsequently conducted in order to compare the identified categories with existing knowledge on career facilitation and asset-based approaches.

\section{ENSURING THE TRUSTWORTHINESS OF THE STUDY}

Trustworthiness was ensured in the study by using various rigour strategies during the data collection and analysis. Table 5 lists the strategies used to guarantee the quality of the study.

Table 5: Strategies to increase and enhance rigour during data collection and analysis

\begin{tabular}{|l|l|}
\hline Rigour during qualitative research phases \\
\hline Confirmability & $\begin{array}{l}\text { Chain of evidence - data, methods and decisions made during the project were } \\
\text { thoroughly documented in various modes (visual photocopies of intervention } \\
\text { artefacts, participant reflections, field notes as well as a researcher diary). } \\
\text { The researcher diary as well as the participant journals represented reflexive } \\
\text { methodological accounting. }\end{array}$ \\
\hline Credibility & $\begin{array}{l}\text { Triangulation - many forms of evidence were collected for diverging and converging } \\
\text { of evidence. } \\
\text { Prolonged engagement in the field - numerous observations were made across } \\
\text { different intervention times and places. } \\
\text { Confinuous observation of the participants (documented in the field notes and } \\
\text { researcher diary) was carried out during the research/intervention phases. }\end{array}$ \\
\hline Dependability & $\begin{array}{l}\text { An audit trail was done to assess the adequacy with which raw data had been } \\
\text { reduced and analysed. }\end{array}$ \\
\hline Transferability & $\begin{array}{l}\text { For reflexivity purposes, observations were documented in a research diary. } \\
\text { Sufficient information was given on the intervention for readers to judge the } \\
\text { applicability of the findings to other known settings. }\end{array}$ \\
\hline
\end{tabular}

(Compiled from Creswell 2003; McMillan and Schumacher 2001; Seale 1999)

\section{ETHICAL ISSUES}

Processes to guarantee the research participants' well-being were implemented throughout the study. Informed assent (participants) and consent (parents) were obtained, and confidentiality was maintained. The researchers gave feedback to the participants during all phases of the intervention and study thus, precluding deception on the part of the researchers.

\section{LIMITATIONS}

The study has some limitations because the intervention was not piloted and also because the intervention differed with the five participants, thus possibly further 
complicating the already complex nature of transferability in qualitative research. Also, the inclusion of audio-recordings of the intervention could have increased the dependability of the findings by providing verbatim accounts of the participants' as well as the researchers' intervention inputs. The small number of case studies (five case studies) explored and described in the research limits the depth of conclusion as the five cases cannot be considered a representative sample of the South African population. In addition, the type of cases investigated limited conclusions that could be drawn with regard to other cultures because of the lack of diversity in the cases. Therefore, research with a lager quantity and more diverse group of participants is warranted before any transferable inferences may be made.

\section{PRESENTATION OF THE RESULTS}

A qualitative investigation proposed three major themes. Table 6 illustrates the major themes, associated sub-themes and supporting evidence from data sources. What follows is a discussion of each major theme set and its corresponding sub-themes against the backdrop of existing literature.

Table 6: Emerging themes, sub-themes and excerpts from field notes and research diaries

THEME 1: IMPACT OF INDIVIDUAL CLIENT-PARTNER PROFILES ON THE USE OF ASSET-BASED PRINCIPLES

Sub-theme: Influence of personality traits of the client-partner on the use of asset-based strategies in career facilitation.

Diary reflection about The Thinker: 'He seems pleased with the process of exploration using people and institutions around him'. In this regard, the facilitator wrote the following during a session with The Undecided: 'She has not done research on the above interests ... and seems eager to participate in the exploration'.

The Decided wrote in her reflection: 'I wish for anyone ... to make contact with reality'.

In this regard, The Undecided wrote the following in her participant reflection: 'I feel that the sessions did not determine which other careers would be suitable for $\mathrm{me}^{\prime}$.

The Undecided's preference for logical and non-personal judgments was clear when she said, 'I feel like we are getting nowhere' and 'more time could have been spent on aptitude tests'. Another example is the way in which The Thinker wanted to reason through activities in order to reach logical conclusions. In this regard, the facilitator wrote at the start of one of the sessions with him: 'Before we started the session he wanted to discuss a matter'. His need to reflect logically about events seemingly hampered the flow of the asset-based career facilitation process since a lot of time was spent on reasoning about the choice of media. The Golfer came to his own logical conclusion that he will not excel in any other career except playing golf professionally. This conclusion is substantiated by the fact that he did not want to consider any other career option. Therefore, the process of exploring different options was not viable for him.

The Undecided preferred to search for information on the internet, and The Thinker quit the process before we could mobilise the support from his environmental asset map.

It could not be said for certain that The Architect, who believed she had found her ideal career, and The Decided, who had made her final choice, or The Golfer who believed he would live his dream, were boasting impractical ambitions. Their talents and achievements seemed to prove otherwise. The Architect's passion and determination, together with her aptitude, indicated a great possibility of success in her ideal career. The Decided's enthusiasm and imagination, in conjunction with a high technical ability, supported her choice. The Golfer's devotion and dedication seemed to be a viable driving force to ultimately live his life's dream. 
Through being part of a career facilitation process whereby these clients could participate in voicing their dreams and viewing some part of reality in terms of career, it could be said that they took one step closer to their dreams.

In this regard, The Golfer shared such a preference for flexibility as was illustrated during one session when he forgot his homework assignment but was flexible enough to 'compile an asset map anyway, using the information from his memory'. The Architect was flexible enough to accommodate me in her living room, seeing that there was not an office space available to conduct the career facilitation sessions with her. The Decided showed her flexibility by being comfortable enough to conduct the assetbased career facilitation process via the telephone.

\section{Sub-theme: Age of client-partners}

Completing the developmental task of emancipation seemed to support the asset-based approach's goal of the client-partner taking responsibility and is illustrated in the next reflection. The facilitator wrote in the research diary: 'He wants to be in control - which means he does not like people telling him what to do'.

It could be said that The Undecided, who appeared to struggle with committing to the process of taking ownership and mobilising her assets, was still developing her sense of self. She cancelled many appointments (refer to Appendix B) and wanted me to give her a career choice answer. She chose the Internet as her asset and had to find information on her career interests as a homework assignment. During the feedback session, the facilitator reflected that 'I got the idea she just did this in half an hour because it seemed that she had not read through the information'.

\section{Sub-theme: Unique family dynamics}

Evidence of this resides with The Architect's parents who said that they 'raised their daughter to be able to look after herself one day. They felt strong about her working hard for her money'.

Examples to demonstrate this are: The Thinker 'has many people (friends of his father and others) lined up to speak with'; The Architect 'already spoke with her mother's uncle about fashion design'; and The Undecided's 'mother went to a dietician whom she can also visit to find out what a dietician does'.

\section{Sub-theme: Career interest profile of client-partner}

The Architect started with an undifferentiated profile as she was interested in architecture, jewellery design and fashion design. Even though the careers are related, she was not sure which one would be the best for her. It seemed that through asset-based career facilitation she recognised that she was interested in fashion design and jewellery design but soon realised she 'had a dream to become an architect'. In this regard, she reflected the following, 'we were at the architect and I heard very interesting things. This is my ideal work, no other work for me, thank you! The work is mine!' Thus, through asset-based career facilitation, the client-partner can narrow down career interests in order to commit to a career choice.

The Golfer was differentiated in terms of his career interest as he had made his choice to become a professional golfer. The Golfer related that 'Plan A was to become a golfer; he did not want to think about a Plan B. If there was a Plan B, then the motivation to give up Plan A would be bigger because of the opportunity to fall into the safety of a Plan B. Therefore, he'd rather work harder at Plan A than fall into the safety of a Plan B'. This viewpoint of The Golfer changed the focus of the career facilitation process from exploring different careers to exploring different ways to reach his dream. As such, the asset-based career facilitation process can be used as a flexible framework within which a clientpartner's career development path can be improved in addition to committing to a career choice. The Decided appeared to be differentiated as well as she made her career choice before she took part in this study. She agreed to participate in the study to confirm her choice. After the process, she reflected, 'for a learner like me who had not made contact with an architect, it was a very informative event'. She found confirmation and commented that she 'now had a picture in mind to work for'.

Sub-theme: Previous career assessment experience of client-partner

The first need the facilitator identified was the need to explore the possible careers that had been suggested during the career assessment. In this regard, the facilitator reflected as follows about The Undecided: 'A psychologist named a couple of careers and these seemed interesting to her'. 
Following this comment, the facilitator explained how traditional career counselling differed from the alternative perspective, and 'they seemed pleased' with the process. After completion of the career facilitation process, she reflected that she 'had discovered which of the three careers she liked ... and knew now which universities she could go to, and how many years she would need to study'. An example of this need became evident when The Decided agreed to be part of the asset-based career facilitation process in order to verify a suggestion made by a previous career counsellor. The same applied to The Undecided who was given three or four career options by her career counsellor prior to the asset-based career facilitation process.

For example, The Architect's aptitude was assessed but, according to her, the results were not explained, resulting in her not understanding what the different scores meant. She wanted to know whether or not her profile fitted into a profile for an architect. During the facilitation sessions, we compared her new-found knowledge of architecture with her existing knowledge (aptitude profile), and she reflected: 'It made me think, and it was quite nice! It was my ideal work!' The Thinker expected more from his career counsellor who had advised him that he could choose any career he wanted.

\section{Theme 2: Challenging role of the asset-based career facilitator in career facilitation sessions}

'We asked the architect's assistant to tell us about being an architect. I saw the architect's assistant being a bit nervous because she had a dry mouth and flushed red as she seemingly struggled to put her life's work into words. Immediately, I wondered about the way in which people experience being part of a collaborative effort for the first time. It seemed that the client-partners listened with great attention and asked many questions. I experienced my role in the situation also as facilitator because I reflected on what the architect said and asked questions that I thought the client-partners missed. Another thought came to mind: I now have first-hand information which I can share with another client-partner who has the same interest.'

Therefore, the facilitator needed to backtrack many times. In this regard, the facilitator reflected about my thinking during a session with The Golfer: 'I realised I was too quick for the process. I could see the links between the assets and the information he needed. I found it very difficult to backtrack and explain my thinking (alternative approach) to him in order for him to see where we were going. When he realised what the process was about - that in order to have as much info on a career as possible, you can use your assets (self and environment) to obtain it, the session went a lot smoother- then he added golfing magazines and the internet to his asset map. In addition, we found that he knew two professional golfers with whom he had already established a relationship and he could contact them! We realised he actually knew a lot about his dream career already.'

THEME 3: IMPACT OF THE OLD PARADIGM ON THE USE OF ASSET-BASED PRINCIPLES

Sub-theme: Client-partner's expectation that career facilitator is an expert

Focusing on facilitation became difficult when The Undecided appeared to expect something different from what was offered through facilitation. The Undecided reflected later, 'I felt that the sessions did not determine any other careers that would suit my specific aptitude'. The facilitator experienced the client's attitude as expecting the facilitator to be an 'old paradigm career counsellor' who could offer solutions to her career path questions. In addition, she felt frustrated with the lengthy process and commented that 'it could rather be one whole morning or day than one day per week for a month'.

Sub-theme: Resistance of the client-partner to be part of partnership

It seems that The Undecided was reluctant to form a partnership in the asset-based career facilitation process because as client-partner and career facilitator we did not share a common goal. My assetbased career facilitation goal for The Undecided was for her to explore the career options she experienced at the time of the career facilitation. Seemingly, her goal was for me to advise her on new careers. She expected me to be the expert and to fit her personal profile to a suitable career environment.

In this regard, The Undecided was experienced as resisting participation in the career facilitation process as she apparently expected me to make the career choice on her behalf. Furthermore, she gave the impression that she was hesitant to contact other stakeholders because she listed a dietician and explained how accessible this asset was but never got around to contacting the dietician. 
The Architect, on the other hand, did not resist being a partner because she acted on the common goal (which was to find career information), and she phoned several universities to enquire about admission regulations. The same could be said of The Golfer who contacted his professional golfer friends to enquire about golfing bursaries.

\section{Impact of individual client-partner profiles on the use of asset- based principles}

This theme indicates that the influence of certain personal characteristics of clientpartners emerged as a significant factor when using asset-based career facilitation as a post-modern method in career guidance. In this regard, the following sub-themes of personal characteristics surfaced: personality traits, age, unique family dynamics, career interest profile and previous career assessment experiences.

\section{Influence of personality traits of the client-partner on the use of asset-based strategies in career facilitation}

Table 7 summarises the personality type of each participant according to the MyerBriggs Type Indicator ${ }^{\circledR}$ (Healy and Woodward 1998). Introverts 'are not as likely to build social networks as are extroverts and they may be less inclined to elicit support from others for their career plans' (Healy and Woodward 1998, 76). In this regard, the introverted participants were seemingly uncomfortable when it came to collaborating with other stakeholders in their environment. Conversely, the extraverted participants apparently had no trouble contacting stakeholders such as businesses and universities. Moreover, the feeling-orientated participants contacted other stakeholders possibly because 'feeling clients tend to be more attuned to the values of others so that they may be more inclined to connect with people and form networks' (Healy and Woodward 1998, 78).

Table 7: $\quad$ Personality profiles of participants according to the Myers-Briggs Type Indicator ${ }^{\circledR}$

\begin{tabular}{|c|c|c|c|c|c|c|}
\hline \multicolumn{7}{|c|}{$\begin{array}{l}\text { Personality profiles according to the Myers-Briggs Type Indicator }{ }^{\circledR} \\
\text { (Healy and Woodward 1998) }\end{array}$} \\
\hline $\begin{array}{l}\text { Profile } \\
\text { Scale }\end{array}$ & The Thinker & The Golfer & The Undecided & The Architect & $\begin{array}{l}\text { The } \\
\text { Decided }\end{array}$ & $\begin{array}{l}\text { The } \\
\text { Facilitator }\end{array}$ \\
\hline $\begin{array}{l}\text { Direction of } \\
\text { energy }\end{array}$ & $\begin{array}{l}\text { Introvert } \\
\text { (I) }\end{array}$ & $\begin{array}{l}\text { Extrovert } \\
\text { (E) }\end{array}$ & $\begin{array}{l}\text { Introvert } \\
\text { (I) }\end{array}$ & $\begin{array}{l}\text { Extrovert } \\
\text { (E) }\end{array}$ & $\begin{array}{l}\text { Extrovert } \\
\text { (E) }\end{array}$ & $\begin{array}{l}\text { Introvert/ } \\
\text { Extrovert } \\
(\mathrm{I} / \mathrm{E})\end{array}$ \\
\hline $\begin{array}{l}\text { Information } \\
\text { gathering }\end{array}$ & $\begin{array}{l}\text { Sensing } \\
\text { (S) }\end{array}$ & $\begin{array}{l}\text { Intuitive } \\
(\mathrm{N})\end{array}$ & $\begin{array}{l}\text { Sensing } \\
\text { (S) }\end{array}$ & $\begin{array}{l}\text { Intuitive } \\
(\mathrm{N})\end{array}$ & $\begin{array}{l}\text { Intuitive } \\
(\mathrm{N})\end{array}$ & $\begin{array}{l}\text { Intuitive } \\
(\mathrm{N})\end{array}$ \\
\hline $\begin{array}{l}\text { Decision } \\
\text { making }\end{array}$ & $\begin{array}{l}\text { Thinking } \\
\text { (T) }\end{array}$ & $\begin{array}{l}\text { Thinking } \\
\text { (T) }\end{array}$ & $\begin{array}{l}\text { Thinking } \\
\text { (T) }\end{array}$ & $\begin{array}{l}\text { Thinking } \\
\text { (T) }\end{array}$ & $\begin{array}{l}\text { Feeling } \\
\text { (F) }\end{array}$ & $\begin{array}{l}\text { Feeling } \\
\text { (F) }\end{array}$ \\
\hline Lifestyle & $\begin{array}{l}\text { Judging } \\
\text { (J) }\end{array}$ & $\begin{array}{l}\text { Perceiving } \\
\text { (P) }\end{array}$ & $\begin{array}{l}\text { Judging } \\
\text { (J) }\end{array}$ & $\begin{array}{l}\text { Perceiving } \\
\text { (P) }\end{array}$ & $\begin{array}{l}\text { Perceiving } \\
\text { (P) }\end{array}$ & $\begin{array}{l}\text { Perceiving } \\
\text { (P) }\end{array}$ \\
\hline
\end{tabular}


Sensing-orientated clients prefer to gather information using known facts and data (Van Rooyen et al. 2001). Research done by Coetzee and Schreuder (2002) supports the fact-seeking attitude of sensing-orientated clients. In this study, the sensingorientated clients seemed excited about the prospect of using existing resources. The possibility of using existing resources might have been compelling to them as they preferred to gather information through working with the known. Unfortunately, sensing-orientated clients 'prefer to rely on immediate sensation to define reality and on experience to master the world. They may distrust unsubstantiated imagination and vague possibilities' (Healy and Woodward 1998, 77). In this regard, some of the sensing-orientated participants felt frustrated by the absence of factual, test-driven information. In this regard the mobilisation of identified assets were compromised because the information did not come from a standardised instrument.

The more analytical, thinking-orientated client weighs information and solutions offered (Healy and Woodward, 1998). As with most traditional approaches to career counselling, they possibly favoured a test that would tell them what to do (Krumboltz, 1996), and did not expect a flexible and non-linear process (Ebersön and Eloff, 2003). Even though Krumboltz (1996) regards this preference as idealistic, Holland (1996) comments that clients generally do not seek a way to become mature, but rather want to know from the career counsellor what kind of work will bring them happiness. The implication is that they possibly preferred the outcome of the asset-based career facilitation process to differ from what was offered, resulting in their experiencing frustration and hindering the process of attaining knowledge.

According to Van Rooyen et al. (2001), perceiving-orientated clients are flexible, spontaneous and open to different possibilities. In this regard, the participants who were perceiving-orientated accommodated sudden changes and showed flexible attitudes. Research has established the positive influence of self-efficacy on career choice (Betz 2004; Paulsen and Betz 2004). According to the social-cognitive career theory of Lent, Brown and Hackett (1996), some participants' positive attitudes and self-efficacy expectations ${ }^{1}$ can be seen as a driving force in their belief in their own future success.

\section{Age of client-partners}

During the asset-based career facilitation process, we emphasised progressive maturity as a way of taking ownership of the process. Although all the participants were within the exploration phase of career development, it appeared as if the youngest participant (16 years old) struggled to commit to the process of taking ownership in contrast to the older participants who seemingly felt more at ease with the process. Parmer and Rush $(2003,26)$ write: 'Opportunities exist for the profession to assist clients in redefining their careers on the basis of ownership'. Research findings indicate that age is a relevant demographic variable that determine career exploration (Ketterson and Blustein 1997). According to the lifespan lifespace approach to career development, persons between the ages of 14 and 24 are in the exploration phase of career development (Super, Savickas and Super 1996). 
Super explains the exploration phase in career development as a phase during which people focus on their own needs and identity, learn new skills, test dreams in the real world and verify career choice thus becoming mature enough to choose a career (Super et al. 1996).

\section{Unique family dynamics}

The study showed that parents who support their children in making independent choices and utilising assets assist the asset-based approach, implying that such children tend to be comfortable as part of a collaboration team. The following extracts substantiate our claim. Form our field note observations it is apparent that the Architect's parents felt they 'raised their daughter to be able to look after herself one day. They feel strong about her working hard for her money;' and 'she already spoke with her mother's uncle about fashion design'. Similarly during informal conversations we observed that The Thinker 'has got many people (friends of his father, etc.) lined up to speak with'. In her case, The Undecided's 'mother went to a dietician whom she can also visit to find out what a dietician does'.

The influence of family dynamics has received considerable attention in previous research. For example, Kracke $(1997,348)$ found that 'with respect to the influence of parental behaviors on adolescent career exploration, the results indicate that more child-centered, supportive, and reciprocal parent-adolescent relationships relate to more active exploration'. Ketterson and Blustein (1997) obtained similar results in their research and concluded that secure relations between parents and siblings are associated with career exploration. More recent research confirms these results (Flouri and Buchanan 2002; Turner and Lapan 2002).

\section{Career interest profile of client-partner}

Herr and Cramer $(1996,627)$ write that 'increasing occupational information per se has been found not to lead to an increase in vocational differentiation'. Therefore, in terms of asset-based career facilitation, this sub-theme seems to underscore the views of $\mathrm{Nel}(1999,55)$ who says 'the implication ... is that the undifferentiated person will have greater difficulty in deciding on a career, while it is easier for the differentiated person to make a choice'. The present study showed that undifferentiated ${ }^{2}$ as well as differentiated participants can benefit from an asset-based career facilitation process. The findings indicated that such a process benefited the participant who was faced with the challenge of having too many career options as well as the participant who felt threatened by the challenge of having one choice and no career development path.

\section{Previous career assessment experience of client-partner}

Herr and Cramer (1996) suggest that a client-centred approach in career counselling can provide a safe and accepting environment in which career planning may be explored. The client-partners who took part in career assessments prior to this study seemed to have differing perceptions about the asset-based career facilitation 
process. However, these perceptions did not necessarily hinder the asset-based career facilitation process because the process apparently addressed some needs that arose from previous assessments. Firstly, it seemed that some of the participants needed confirmation of career guidance done previously. Secondly, some of the participants seemed dissatisfied with the explanation of results during previous career assessments. Thirdly, when seemingly vague recommendations had been made previously, the participants indicated a need for more guidance from the career facilitator in terms of facilitating career development.

\section{Challenging role of the asset-based career facilitator in career facilitation sessions}

This theme highlights the challenging role of the career facilitator when applying an asset-based approach. Practical issues surfaced with regard to site visits, the experience of stakeholders and the explanation of the concept of an asset map.

Firstly, although the decision to join some participants on a visit to an architect friend seemed useful because of the valuable career information gained, many questions arose regarding the experience and expectations of the people who were visited and consequently, the process of asset mobilising as a whole. The stakeholder in this study was not briefed beforehand and in some respects seemed unprepared for the situation. In this regard, Lapan, Osana, Tucker and Kosciulek $(2002,173)$ write: 'Community career partnerships have the potential to draw into working alignment the critical aspects of career development and the key social contexts that can either promote or inhibit growth'.

Secondly, it could be argued that with a larger pool of clients, the actual site visit would not be practical due to time constraints. Thirdly, notwithstanding the challenge of explaining the asset-based approach to the participants, the study revealed the use of the asset map as a crucial part of the career facilitation process. Asset mapping is indispensable as a means of listing possible familiar sources of career information. Consequently, the asset map technique is a helpful tool for focusing on reference points for gathering career information on condition that the participant fully understands the reason for and the use of creating an asset map.

\section{Impact of the old paradigm on the use of asset-based principles}

This theme suggests that the traditional medical paradigm is currently somehow crystallised in career facilitation practices. In this regard, the following sub-themes emerged: firstly, clients still expect career facilitators to be all-knowing experts; and secondly, clients resisted accepting the responsibility being actively involved in the career facilitation process, thus resisting to form a partnership.

\section{Client-partner's expectation that the career facilitator is an expert}

This new career counselling role is described by Prinsloo (1999) as the joining of personal and career counselling where the career counsellor becomes a facilitator of career development rather than the giver of advice and expert solutions. Facilitating 
the process as described by Prinsloo (1999) was not an easy task because of the entrenched nature of the medical paradigm (Lubbe and Eloff 2004; Ebersöhn and Eloff 2003) and the fact that 'clients enter counselling with varying expectations about the roles they and the counsellor will play' (Whitaker, Phillips and Tokar 2004, 309). The study showed that career facilitators should be alert to the client's counselling goals and it supports Niles, Anderson and Cover's (2000, 142) finding that career counsellors should 'sensitise their clients to the fact that their career counselling goals may need to be revised as the counselling process unfolds'.

Gothard, Mignot, Offer and Ruff (2001, 42-43) emphasise the importance of 'the nature of the relationship between the participants in the career helping process, i.e. that the Rogerian core values of respect, genuineness and empathy need to be present ...', while Weinrach (2003) believes that the person-centred perspective can contribute to career counselling in modern times. In this regard, Multon, EllisKalton, Heppner and Gysbers (2003) stress the significance of a working alliance between the counsellor and client. The present study supports the significance of a changing role for the career facilitator but also shows the difficulty of opposing the traditional approach and the implied client expectations.

\section{Resistance of the client-partner to be part of a partnership}

Lubbe and Eloff $(2004,36)$ write that 'collaboration means the sharing of ideas in a joint decision-making and problem-solving process directed toward a common goal'. Ebersöhn and Eloff $(2003,16)$ describe partnership as 'individuals joining together'. Tang (2003) advocates collaboration as part of future career counselling. In this regard, it became evident that if the participant did not share the asset-based goal of shared responsibility in terms of career exploration, he/she resisted being part of the partnership. By the same token, no resistance was experienced with participants who shared the common goal.

\section{DISCUSSION}

On the basis of the above themes, we developed a set of indicators and contraindicators (see Table 8) to guide the practitioner as to the circumstances that were favourable for using asset-based career facilitation. On the one side of the table, we list characteristics and settings that appear to be conducive to asset-based career facilitation. On the other side, we list characteristics and settings that seem to hinder the application of the asset-based approach in career facilitation.

Table 8: Indicators and contra-indicators for the use of asset-based career facilitation

\begin{tabular}{|l|l|}
\hline Indicators & Contra-indicators \\
\hline - An asset-based career facilitation process can & - An asset-based career facilitation process \\
$\begin{array}{l}\text { contribute to the refinement of career interests } \\
\text { after a more traditional career assessment resulted } \\
\text { in undifferentiated career interest profiles. }\end{array}$ & $\begin{array}{l}\text { may seem boring and as a repetition of } \\
\text { traditional career assessment procedures if } \\
\text { the same results are obtained. }\end{array}$ \\
\hline
\end{tabular}


- An asset-based career facilitation process seems to work well where there is a trusting, open and collaborative relationship between the career facilitator and the client-partner.

- Psychometric tests that allow the client-partner and the career facilitator to deliberate on the results fit into the asset-based viewing of the client-partner.

- The asset-based career facilitation process seems to be favourably influenced by client-partners who seem to be natural asset users.

- An asset-based career facilitation process appears to be indicated when the personal preferences of the client-partner constitute flexibility, networking and open-mindedness.

- An asset-based career facilitation process seems to be indicated when the client-partner will be entering the workforce in the near future.

- An asset-based career facilitation process seems to be indicated when the family of the client-partner is recognised as a system of assets by the clientpartner.

- The profile of an asset-based career facilitator seems to be a person who is flexible, adaptable and open-minded.

- The profile of a client-partner who may benefit from an asset-based career facilitation process appears to be that of a client-partner who is at the age of entering the workforce; has a supportive family; and has more or less the same personality preferences as the career facilitator.
- An asset-based career facilitation process seems to be hindered if client-partners do not understand or are not able to adhere to the principles of the asset-based approach.

- An asset-based career facilitation process appears to be restricted by client-partners who expect 'traditional' expert advice from the career facilitator.

- If the client-partner resists being part of the asset-based partnership, the assetbased career facilitation process may be contra-indicated.

- If the client-partner is not able to commit to a lengthy process of exploration and self-growth, the asset-based career facilitation process may be contraindicated.

- An asset-based career facilitation process is contra-indicated when the client-partner seeks structure and control during the career facilitation process.

- An asset-based career facilitation process appears to be contra-indicated when client-partners expect the career facilitator to inform them on career information.

- If the personality profile of the clientpartner is in direct contrast with the personality profile of the career facilitator, the career facilitation process may be hindered. Having said this, career facilitators should be aware of potential differences in personality profiles and ways to overcome this particular challenge aligned with post-modern approaches to career counselling.

The study showed that the asset-based approach could be regarded as a post-modern alternative to managing career development. However, as some client-partners still prefer a traditional person-environment fit model, the expectations of clients as well as those of the career facilitator compromise the application of a paradigm shift in a helping profession such as career facilitation. If a client does not fulfil the role required by a paradigm shift, it may make sense to be flexible and apply an approach that makes him/her feel more comfortable. The present study indicates that the assetbased career facilitator should be sensitive to the specific preferences of the clientpartner. It stresses the importance of a flexible stance and an openness to adapt to client-partners' choices with regard to the way they prefer to gather career and selfinformation as well as make career decisions.

The findings of this study indicate that asset-based strategies can be fitted into and made part of traditional career counselling. The findings show that an asset- 
based approach can be applied successfully in career facilitation using asset-based principles such as collaboration, client-partner ownership, shared responsibility between facilitator and client-partner, thus enabling the client-partner through the identification and practice of sustainable career developmental skills. In the study, asset-based strategies such as post-modern exploration strategies, asset mapping and asset mobilisation proved functional within the career facilitation process. Based on the findings, we recommend that career facilitators should be trained in asset-based strategies and principles as tools to facilitate career development in clients. The use of asset-based strategies was found to be meaningful in the career facilitation of a small group of adolescents within the career exploration phase. Asset mapping specifically was shown to be an effective technique during career facilitation and should therefore be included in training programmes.

The value of applying an asset-based approach in career facilitation lies in viewing client-partners as equal contributors in their own career development processes, in cultivating sustainable career development skills and in facilitating access to authentic career situations against which the career choices of client-partners can be measured. The findings of the study suggest the importance of training career facilitators to use different career facilitation techniques and to identify the facilitation preferences of client-partners.

The study indicates the need for further research to determine the experiences of stakeholders in collaborative career facilitation. In order to meet the vast need for career facilitation in South Africa, research is required on the feasibility of applying asset-based career facilitation in group settings, specifically as part of the curriculum in schools. Research on the reciprocal influence of the personality traits and personal preferences of career facilitators and client-partners could favourably influence career facilitation practice and training. An asset-based approach is one way of addressing the issue of limited indigenous career development strategies available in South Africa. More research on indigenisation and indigenous career development strategies is also needed.

\section{NOTES}

1 Self-efficacy expectations refer to individuals' beliefs about their capabilities to perform a particular task (Bandura 1997).

2 An undifferentiated person may be 'swayed by every environmental demand that is placed on him or her' (Nel 2006, 41). 


\section{REFERENCES}

Akhurst, J. and N. C. Mkhize. 2006. Career education in South Africa. In Career psychology in the South African context, ed. G. B. Stead and M. B. Watson, 139-153. Pretoria: Van Schaik Publishers.

Angrosino, M. V. and K. A. Mays de Pérez. 2000. Rethinking observation. In Handbook of qualitative research, ed. N. K. Denzin and Y. S. Lincoln, 673-702. Thousand Oaks: Sage Publications.

Bandura, A. 1997. Self-efficacy: The exercise of control. New York: W.H. Freeman.

Betz, N. E. 2004. Contributions of self-efficacy theory to career counselling: A personal perspective. The Career Development Quarterly 52(4): 340-353.

Coetzee, M. and A. M. G. Schreuder. 2002. The relationship between career patterns and personality types. South African Journal of Industrial Psychology 28(1): 53-59.

Coetzee, S. 2005. Investigating the application of the asset-based approach in career facilitation. Unpublished Master's dissertation. Pretoria: University of Pretoria.

Cosser, M. 2002. Factors affecting student choice behaviour in the course of secondary education with particular reference to entry into higher education. Research Report. Pretoria: HSRC.

Creswell, J. W. 2003. Research design. Qualitative, quantitative and mixed methods approaches. Second edition. California: Sage Publications.

- 2005. Educational research. Planning conducting and evaluating quantitative and qualitative research. New Jersey: Pearson Education.

Denzin, N. K. and Y. S. Lincoln. 1998. The landscape of qualitative research. London: Sage Publications.

Donald, D., S. Lazarus and P. Lolwana. 2002. Educational psychology in the social context. Second edition. Cape Town: Oxford University Press.

Durrheim, K. 2002. Research design. In Research in practice, ed. M. Terre Blanche and K. Durrheim, 29-53. Cape Town: University of Cape Town Press.

Ebersöhn, L. 2007a. Voicing perceptions of risk and protective factors in coping in a HIV\&AIDS landscape: reflecting on capacity for adaptiveness. Gifted Education International 23(2) (IBSS Journal).

- 2007b. Utilising reminiscences: constructing boxes of memories to tell stories for life choices. In Shaping the story. A guide to facilitating narrative counselling, ed. K. Maree. Pretoria: Van Schaik Publishers.

Ebersöhn, L. and Eloff, I. 2003. Life skills and assets. Pretoria: JL van Schaik.

- 2006. Life skills and assets. Second edition. Pretoria: JL van Schaik.

—. 2007. Shades of graduating: colour lessons from postgraduate studies employing photographic methodology. In Putting people in the picture: Visual methodologies for social change, ed. N. de Lange, C. Mitchell and J. Stuart. Sense Publishers.

Flouri, E. and A. Buchanan. 2002. The role of work-related skills and career role models in adolescent career maturity. The Career Development Quarterly 51(1): 36-43.

Gothard, B., P. Mignot, M. Offer and M. Ruff. 2001. Careers guidance in context. London: Sage Publications.

Healy, C. C. and G. A. Woodward. 1998. The Myers-Briggs Type Indicator and career obstacles. Measurement and Evaluation in Counselling and Development 32(2): 74 86. 
Herr, E. L. and S. H. Cramer. 1996. Career guidance and counselling through the life span. Systematic approaches. Fifth edition. New York: Longman.

Holland, J. L. 1996. Integrating career theory and practice. The current situation and some potential remedies. In Handbook of career counselling theory and practice, ed. M. L. Savickas and W. B. Walsh, 1-11. Palo Alto, CA: Davies-Black.

Jassat, M., J. Akhurst and C. Adendorff. 2006. Career information: sources, services and classification. In Career psychology in the South African context, ed. G. B. Stead and M. B. Watson, 139-153. Pretoria: Van Schaik Publishers.

Ketterson, T. U. and D. L. Blustein. 1997. Attachment relationships and the career exploration process. The Career Development Quarterly 46(2): 167-177.

Kracke, B. 1997. Parental behaviours and adolescents' career exploration. The Career Development Quarterly 45(3): 341-350.

Krieshok, T. S., S. Hastings, C. Ebberwein, K. Wettersten and A. Owen. 1999. Telling a good story: Using narratives in vocational rehabilitation with veterans. The Career Development Quarterly 42(2): 202-214.

Krumboltz, J. D. 1996. A learning theory of career counselling. In Handbook of career counselling theory and practice, ed. M. L. Savickas and W. B. Walsh, 55-80. Palo Alto, CA: Davies-Black.

Langley, R. 1999. Super's theory. In Career psychology in the South African context, ed. G. B. Stead and M. B. Watson, 67-90. Pretoria: JL van Schaik.

Lapan, T. R., H. P. Osana, B. Tucker and J. F. Kosciulek. 2002. Challenges for creating community career partnerships: Perspectives from practitioners. The Career Development Quarterly 51(2): 172-191.

Lather, P. 1991. Getting smart: Feminist research and pedagogy within the postmodern. New York: Routledge.

Lent, R. W., S. D. Brown and G. Hackett. 1996. Career development from a social cognitive perspective. In Career choice and development, ed. D. Brown, L. Brooks and Associates, 373-421. Third edition.

Lubbe, C. and I. Eloff. 2004. Asset-based assessment in educational psychology: capturing perceptions during a paradigm shift. The California School Psychologist 9:29-38.

Maccoby, M. 1981. The leader: A new face for American management. New York: Simon and Schuster.

Maree, J. G. (Ed.). 2007. Shaping the story - a guide to facilitate narrative counselling. Pretoria: Van Schaik Publishers.

Maree, J. G. and G. Beck. 2004. Using various approaches in career counselling for traditionally disadvantaged (and other) learners: some limitations of a new frontier. South African Journal of Education 24(1): 80-87.

Maree, K. 2002. Theoretical approaches: An overview. In Lifeskills and career counselling, ed. K. Maree and L. Ebersöhn, 4-32. Cape Town: Heinemann.

Maree, K. and L. Ebersöhn, L. 2007. Applying positive psychology to career development. Interventions with disadvantaged adolescents. In Theorising children's and adolescent's career development, ed. V. Skorikov and W. Patton. Sydney: Sense Publishers.

Marshall, C. and G. B. Rossman. 1989. Designing qualitative research. Newbury Park, CA: Sage Publications.

Masten, A. S. and M. J. Reed. 2002. Resilience in development. In Handbook of positive psychology, ed. C. R. Snyder and S. J. Lopez, 74-88. Oxford: Oxford University Press. 
McMahon, M. and W. Patton. 2002. Using qualitative assessment in career counselling. International Journal for Educational and Vocational Guidance 2:51-66.

McMillan, J. H. and S. Schumacher. 2001. Research in education: A conceptual introduction. Fifth edition. New York: Addison Wesley Longman Inc.

Moore, C. and V. Rapmund. 2002. Facilitation skills. In Lifeskills and career counselling, ed. K. Maree and L. Ebersöhn, 103-118. Cape Town: Heinemann.

Multon, K. D., C. A. Ellis-Kalton, M. J. Heppner and N. C. Gysbers. 2003. The relationship between counsellor verbal response modes and the working alliance in career counseling. The Career Development Quarterly 51(3): 259-273.

Nel, Z. J. 1999. The career choice theory of John Holland. In Career psychology in the South African context, ed. G. B. Stead and M. B. Watson, 47-66. Pretoria: JL van Schaik.

- 2006. The career choice theory of John Holland. In Career psychology in the South African context, ed. G. B. Stead and M. B. Watson, 35-50. Pretoria: JL van Schaik.

Nicholas, L., A. V. Naidoo and T. B. Pretorius. 2006. A historical perspective of career psychology in South Africa. In Career psychology in the South African context, ed. G. B. Stead and M. B. Watson, 1-10. Pretoria: Van Schaik Publishers.

Niles, S. G., W. P. Anderson, Jr. and S. Cover, S. 2000. Comparing intake concerns and goals with career counseling concerns. The Career Development Quarterly 49(2): $135-144$.

Parmer, T. and L. C. Rush. 2003. The next decade in career counseling: Cocoon maintenance or metamorphosis? The Career Development Quarterly 52(1): 26-34.

Patton, W. 2001. Research Forum Appendix 2 - Career education, what we know, what we need to know. Research Forum Report, September 2001. Queensland: Enterprise and Career education foundation.

- 2005. A postmodern approach to career education: What does it look like? Perspectives in Education 23(2): 21-28.

Paulsen, A. M. and N. E. Betz. 2004. Basic confidence predictors of career decisionmaking self-efficacy. The Career Development Quarterly 52(4): 354-362.

Prinsloo, T. 1999. Loopbaanfasilitering in die veranderde werkskonteks: 'n opvoedkundigesielkundige benadering. Unpublished Master’s dissertation. Johannesburg: University of Johannesburg.

Richardson, M. S. 1993. Work in people's lives: A location for counselling psychologists. Journal of Counselling Psychologists 40:425-433.

Rothman, J. and E. J. Thomas. 1994. Intervention research: Design and development for human service. London: Haworth Press.

Savickas, M. L. 1993. Career counselling in the post-modern era. Journal of Cognitive Psychotherapy: An International Quarterly 7(3): 205-215.

- 1996. A framework for linking career theory and practice. In Handbook of career counselling theory and practice, ed. M. L. Savickas and W. B. Walsh, 191-208. Palo Alto, CA: Davies-Black.

- 1997. Career adaptability: An integrative construct for life-span, life-space theory. The Career Development Quarterly 45(3): 247-259.

- 2005. The theory and practice of career construction. In Career development and counselling: Putting theory and research to work, ed. S. Brown and R. W. Lent, 42e70. New York: John Wiley.

Seale, C. 1999. The quality of qualitative research. London: Sage Publications. 
Super, D. E., M. L. Savickas and C. M. Super. 1996. The life-span, life-space approach to career development. In Career choice and development, ed. D. Brown and L. Brooks, 197-261. Third Edition. San Francisco: Jossey-Bass.

Swart, E. and R. Pettipher. 2005. A framework for understanding inclusion. In Addressing barriers to learning. A South African perspective, ed. E. Landsberg, D. Kruger and N. Nel, 3-20. Pretoria: JL van Schaik.

Tang, M. 2003. Career counselling in the future: Constructing, collaborating, advocating. The Career Development Quarterly 52(1): 61-69.

Thrift, E. and N. Amundson. 2005. Hermeneutic-narrative approach to career counselling: An alternative to postmodernism. Perspectives in Education 23(2): 9-20.

Turner, S. and R. T. Lapan. 2002. Career self-efficacy and perceptions of parent support in adolescent career development. The Career Development Quarterly 51(1): 44-55.

Van Rooyen, J., J. de Beer and D. Proctor. 2001. Myers-Briggs Type Indicator ${ }^{\circledR}$ Training manual. Fifth edition. South Africa: Jopie van Rooyen and Partners.

Watson, M. B. 2004. Post-modern (narrative) career counselling and education. Perspectives in Education 22(1): 169-170.

Weinrach, S .G. 2003. A person-centred perspective to welfare-to-work services: In pursuit of the elusive and the unattainable. The Career Development Quarterly 52(2): 153161.

Whitaker, L. A., J. C. Phillips and D. M. Tokar. 2004. Influencing client expectations about career counseling using a videotaped intervention. The Career Development Quarterly 52(4): 309-322.

Wright, B. A. and S. J. Lopez. 2002. Widening the diagnostic focus. A case for including human strengths and environmental resources. In Handbook of positive psychology, ed. C. R. Snyder and S. J. Lopez, 26-44. Oxford: Oxford University Press. 